\title{
Exploring Relationship between personality, creativity and entrepreneurship: Empirical evidence from an agri- cultural students survey in Taiwan
}

\author{
Jui-Hsiung Chuang ${ }^{1}$, Jiun-Hao Wang ${ }^{2 *}$, Yu-Chang Liou ${ }^{3}$, Szu-Yung Wang ${ }^{4}$ \\ 1, 2,4 Department of Bio-Industry Communication and Development, National Taiwan University, Taipei, Taiwan \\ ${ }^{3}$ Department of Agricultural Economics, National Taiwan University, Taipei, Taiwan
}

\section{Keywords \\ Personality \\ Creativity \\ Entrepreneurship \\ Social enterprise \\ Taiwan}

Received: 5 October 2018

Accepted: 12 November 2018

Published: 11 December 2018

\begin{abstract}
The scarcity of young farmers is a severe structural problem encountered in small-scale agricultural countries. How to encourage agricultural students to enter into farming careers is becoming a political priority for agricultural policy. Previous studies suggested that proactive entrepreneurship is regarded as an important driver for business expansion in rural areas. Agriculture-related social enterprises are seen as a crucial solution to the challenges faced and have gradually become part of mainstream business in rural areas. However, there is limited research available on individual traits and factors that affect students' intentions to set up agri-business to pursue a social and/or environmental contribution. The purpose of this study is to investigate the effect of personality traits and creativity factors of university students on their social entrepreneurship. A survey was designed to measure social entrepreneurial intentions as a dependent variable and personality traits and creative ability as explanatory variables. A face-to-face interview was conducted and targeted the students in two national universities and followed a systematic sampling scheme during October and November 2017. A total of 585 respondents were obtained. A Structural Equation Modeling was used to examine causal relationships among latent variables. The results show that social entrepreneurship is positively influenced by the personality traits of agricultural students directly. However, the creative ability does not have a direct impact on entrepreneurial intentions significantly. Our results reveal that creativity is mediated by personality traits and affects social entrepreneurship intention indirectly. This study contributes to a better understanding of the structural relationship between personality, creativity, and social entrepreneurship by developing and testing a structure model. The main policy implication of this study can be inferred. In addition to professional creativity courses, we suggest that educators and policymakers regarding entrepreneurship education need to pay more attention to the general education courses related to personality re-shaping. To enhance extraversion, emotional stability, and openness of personality traits may serve agricultural students better to engage in social entrepreneurship after their graduation.
\end{abstract}

(C) 2018 The Author(s). Published by TAF Publishing.

\section{INTRODUCTION}

Entrepreneurship plays an important role in the economic growth. Recent researches have paid more attention to entrepreneurship as a crucial driving force to improve industrial competitiveness and increase employment opportunity (Anggadwita \& Dhewanto, 2016; Karimi et al., 2011; Wennekers \& Thurik, 1999). Particularly, many countries have initiated social enterprise promotion policy in re- sponse to social needs and problem resulting from socioeconomies in transition (Bernik, Azis, Kartini, \& Harsanto, 2015; Kerlin, 2006). As social change and economic growth have negatively affected agricultural development in Taiwan, such as the share of agriculture in the GDP has declined gradually. The scarcity of young farmers is a severe structural problem encountered in small-scale agricultural system. How to encourage agricultural students en-

\footnotetext{
*corresponding author: Jiun-Hao Wang

†email: wangjh@ntu.edu.tw
} 
tering into farming career is becoming a relevant policy issue (Wang, Chang, Yao, \& Liang, 2016). Previous studies suggested that a proactive entrepreneurship is regarded as an important driver for business expansion in rural areas. However, current entrepreneurship researches have mainly concerned about students' entrepreneurial intention to the academic fields with promising economic value in Taiwan, for instance information and communication technology (C.-T. Liang, Chia, \& Liang, 2015; Niesing, Merwe, \& Potgieter, 2016), computer and electrical engineering (Bizon, 2016; C. Liang et al., 2017), business management (C.-Y. Hsu \& Wang, 2018) and tourism (Chia \& Liang, 2016). The research interest targeting on agriculture students is still rarely addressed.

The emerging concept of social enterprise is seen as a feasible solution to the agricultural challenges faced in rural Taiwan. The government and agricultural universities have provided practice-related programs, like University Social Responsibility project, corporate internship, agri-business management course and field practice, to encourage students to engage in developing social enterprises in rural areas. Such a clear objective should be promoted that the agricultural social enterprises will gradually form into mainstream businesses in rural areas (Luhmann \& Theuvsen, 2016). Thus, the research problem of this study considers how to promote rural entrepreneurship in agricultural education in Taiwan. This research concern can be formulated as following questions: What factors affect the intention of agricultural students to start a social enterprise? Do the personality traits and creative factors help to provoke students to engage in social enterprise? In what manner do those factors influence the process of shaping social entrepreneurship of agricultural students? What are the implications of agricultural education program for developing social entrepreneurship?

Nevertheless, there is limited research available on individual traits and factors that drive students' intentions to start-up a new agri-business in the context of pursuing social value and/or environmental contribution (Karimi et al., 2011). For example, Wang et al. (2016) recruited participants from agricultural colleges to examine the factor structures of entrepreneurial intention model. Y. Hsu, Peng, Wang, and Liang (2014) conducted imagination and creativity scale, and to analyze their relationship among students majoring in agriculture. Unfortunately, the above-mentioned works focused on general corporate entrepreneurial intention or partial determinants, rather than on the emerging social entrepreneurship.

This study attempts to provide insight into how agricultural colleges can formulate corresponding strategies to enhance students' entrepreneurship competences. To fill this knowledge gap, the purpose of this study aimed at investigating the effect of personality traits and creativity factors of agricultural students on their social entrepreneurship. Special attention is given to the role of inherent personality, which can enhance acquired creativity skills, as well as intensify the originality of newly generated ideas. Hence, this study was designed to examine the intervening role of personality in the structural relationship between creativity and social entrepreneurship.

\section{LITERATURE REVIEW}

\section{Social Entrepreneurship}

The emerging concept of social entrepreneurship has received increased attention by policy makers and scholars worldwide. Kickul and Lyons (2016) indicate that the social entrepreneurship is defined as application of business model, market thinking, and management techniques to pursue social benefits or environmental contribution. The entrepreneurship is characterized as innovative spirit and risk-taking behaviors. Thus, the entrepreneurship is acknowledged as an important motor of growth and job creation (Berglund \& Wennberg, 2006). In addition, the entrepreneur is considered to be more likely to search for new ideas and opportunities which can lead to profitable results. Similarly, the entrepreneur has more willingness to adopt risk-taking actions which is embedded in the innovation (Fillis \& Rentschler, 2010). Different from traditional corporate entrepreneurship, social entrepreneurship focuses on social value and pursuing new opportunities to serve public good, rather than private commercial value. Consequently, social entrepreneurship can be described as process and skill to launch a new business which is responding to social change and solving social problems by using innovative reaction, thereby achieving a sustainable social development (Alvord, Brown, \& Letts, 2004).

Given that the research subjects investigated in this study are university students, we use the social entrepreneurial intentions as the proxy concept of social entrepreneurship. The entrepreneurial intention is recognized as the beginning step of becoming entrepreneurs (Adora, 2017; Krueger Jr, Reilly, \& Carsrud, 2000). Therefore, social entrepreneurial intention refers to self-recognized conviction and preparation for starting up a new business related to social concerns (Thompson, 2009; Wang, Peng, \& Liang, 2014).

Intention is defined as willingness and readiness to take purposive acts and is influenced by the attitude factors. 
Since that entrepreneurship is a planned behavior, the Theory of Planned Behavior (TPB) is commonly adopted to understand entrepreneurial intentions (Ajzen, 1991; Ip, Wu, Liu, \& Liang, 2018; C.-T. Liang et al., 2015). The TPB is useful in explaining why entrepreneurs plan to establish a business, such as motivations and attitudes toward to new business opportunity. However, this TPB based intention model only offers an overall framework for general planned behaviors that may be lack of consideration of features and determinants of entrepreneurial intention, such as creative competence. In this regard, the research model section will further discuss other entrepreneurship theories.

\section{Personality and Entrepreneurship}

Previous entrepreneurship studies have indicated that individual characteristics have impact on decision making in entrepreneurial behaviors (Ip et al., 2018; Lee, Florida, $\&$ Acs, 2004). The big Five-Factor Model (FFM) of personality is an international scale for measuring personality, including extraversion, openness, neuroticism, conscientiousness, and agreeableness (Thompson, 2009). Relationship between personality traits and entrepreneurial behavior is evident and addressed in entrepreneurship literature. Several studies have supported that there are associations between personality traits and entrepreneurship (Zhao \& Seibert, 2006), for instance, higher score of openness, extraversion, and emotional stability reflects stronger entrepreneurial intention.

Personality traits play an influential role in shaping personal decision to start up a new business. Examples of personal traits that are matched to entrepreneurship are extraversion, openness, optimism, and creativity (Ardichvili, Cardozo, \& Ray, 2003; Chia \& Liang, 2016). McCrae and Costa Jr (1995) initiated a concept of characteristic adaptations which refers to some kinds of personality might be mediated by fundamental traits and influenced by external environment and personal experience, such as motivations and attitudes. While the personality of the FFM is regarded as inherited characteristics and appears to be stable and independent after the youth growth stage, creativity is an example of adaptive personality which may be likely to evolve and change throughout individual learning experience. Consequently, the social entrepreneurial model also considers that personality traits might have a mediating mechanism in the relationship between entrepreneurial intentions and other factors (Rauch \& Frese, 2007).

\section{Creativity and Entrepreneurship}

Creativity refers to innovation ability or mental characteristics which can be defined as the ability to develop novel ideas and to find new opportunity in innovative activities, allowing people to adapt to changing environments. Having creative idea and behavior can help entrepreneurs to find new opportunity and keep business grow. Therefore, creativity is also characterized by developing of original and useful products, processes, or practices (Y. Hsu et al., 2014). Since that creativity is a vital component of entrepreneurship, educators suggested that enhancing creative competence will contribute to cultivate students' ability and attitude towards starting new business (Berglund \& Wennberg, 2006).

Several studies also show that entrepreneurship is more likely to generate novel and useful ideas for innovations, pioneering business model and solving problems (Chen \& Chen, 2015; C.-T. Liang et al., 2015). C.-T. Liang et al. (2015) indicated that specific creative ability of entrepreneurs need to take advantage of unique thought (originality) and practical application (usefulness). Although earlier studies revealed that creativity is associated with innovative behavior (Berglund \& Wennberg, 2006; Ward, 2004). The evidence of relationship of students' creativity and entrepreneurial intention is inconsistent. While Chia and Liang (2016) found that creativity has substantial correlation with entrepreneurial intention, a mediation model of creativity in the relationship between entrepreneurial intention and personality traits is only partially supported (C. Liang et al., 2017). By contrary, Karimi et al. (2011) could not provide evidence that creativity has a significant effect on students' entrepreneurial intentions. Such findings suggest that creativity may not be the pre-requisite for students to become an entrepreneur. For those with proper personality, willingness to learn or with active motivation might have more possibility to start up a new business.

\section{RESEARCH MODEL}

\section{Data and Measures}

Data used in this study were drawn from self-conducted survey from October to November 2017. In total, 600 research subjects (third year or above) were recruited from agricultural college of two national universities in southern Taiwan. The sampling method is a systematic sampling scheme.

We first collected agri-business related courses, then chose every 5 th student enrolled in those classes. For each university, 300 students were selected to conduct the study sample. Participation was voluntary, and anonymity was 
guaranteed. After deleting those with missing values in terms of key variables, the valid sample includes 585 students at both graduate and undergraduate levels.

Table 1 shows that among the 585 respondents, of which $50.4 \%$ are male, $39.1 \%$ and $53.8 \%$ are aged 20 or younger and $21-25$ years old. The grad of respondents is $47.9 \%$, $37.9 \%$ and $22.2 \%$ for junior, senior and graduate students, respectively.

TABLE 1. Descriptive statistics of research subjects

\begin{tabular}{|c|c|c|c|}
\hline & Variables & Frequency & $\%$ \\
\hline \multirow[t]{2}{*}{ Gender } & male & 295 & 50.4 \\
\hline & female & 290 & 49.6 \\
\hline \multirow[t]{3}{*}{ Grad } & junior students & 280 & 47.9 \\
\hline & senior students & 222 & 37.9 \\
\hline & graduate students & 83 & 14.2 \\
\hline \multirow[t]{3}{*}{ Age } & 20 or below & 229 & 39.2 \\
\hline & $21-25$ & 315 & 53.8 \\
\hline & 26 or above & 41 & 7.0 \\
\hline
\end{tabular}

To ensure reliable and valid measurements of latent variables, the questionnaire design refers to previous researches as discussed in the literature section. The questionnaire comprised a total of 40 questions. This study adopted a short form of the International English Big-Five Mini-Markers to measure entrepreneurship related personality (Thompson, 2008), which excluded the negative emotion suggested by C.-T. Liang et al. (2015). In addition, a 12-item scale was used to measure creativity and divided into originality and usefulness according to the studies of (Chia \& Liang, 2016). Entrepreneurial intention was measured by 8-items scale, with two dimensions of conviction and preparation (Wang et al., 2016), were adapted for this study. All questionnaires were made use of a 6-point Likert scale $(1=$ strongly disagree to 6 = strongly agree) questions.

\section{Statistical Method}

The statistical analysis of this study included three steps. Due to using structural equation modelling (SEM) to test research hypotheses, we firstly used the skewness-kurtosis tests to confirm the normality assumption. The results show that all variables in the SEM had skewness and kurtosis indices smaller than 1 and did not violate the assumptions of normality, as suggested by Hair, Anderson, Tatham, and Black (1998). Moreover, in the measurement model, we employed the Confirmatory Factor Analysis (CFA) to assess Goodness-of-Fit and construct validity, including factors of originality, usefulness, extraversion, openness, neuroticism, conviction, and preparation. Thirdly, we established a path model to test H1, H2, and H3 (Figure 1). This study further used a mediation model to test the extent to which personality traits and creativity influence the willingness to get involved in social enterprise. This research thus hypothesized that, H4: There is a mediating effect of personality between creativity and social entrepreneurship.

In addition to the TPB as mentioned above, this study also referenced the entrepreneurial event model (EEM) to conduct the structural model of entrepreneurial intention. Parallel to the TBP, Shapero and Sokol (1982) developed the EEM which included five elements of entrepreneurship, i.e., initiative-taking, consolidation of resources, management, autonomy, and risk-taking. The EEM suggested that perceived desirability and feasibility is important determinant of shaping entrepreneurial intentions. Although the TBP and the EEM is two generally accepted intension models, the TPB takes demographic characteristics and personality traits into account, treated those external factors as the antecedents of behavioral intention. On the other hand, the EEM directly focuses on the issue of entrepreneurial intention, rather than intention to general purposeful behavior. Moreover, Shapero and Sokol (1982) argues that the EEM has provided more sufficient predictors to evaluate individual intension. Thus, it is not necessary to include additional variables into the analysis model.

There is considerable empirical evidence based on these theories and shows that people formatting attitude, performing creativity will match their personality (Kolvereid \& Moen, 1997; Varca, 2004). the literature on personality also suggests that students with positive emotional traits are more likely to propensity to take risk, need for achievement, need for independence, self-efficacy (Karimi et al., 2011). It is logical to suggest that different students have difference in mentality, preference, attitude, and react accordingly that matches their personality. Consequently, the structural model of this study integrated the frameworks based on the TPB and EEM to synthesize primary studies on personality, creativity and entrepreneurial intention. This research uses the personality as a mediating variable because of the personality might affect the direction and intensity of creativity on entrepreneurial intention. If the proposed mediating effect is supported, this would suggest that creative educational program should make efforts to customize our training programs to suit the specific need and preference of students, by considering inherent personality traits. Because that these efforts can contribute to enhance the effect of creativity on setting up a social enterprise. The survey data were then analyzed by using SPSS 21 for descriptive statistics and AMOS 21 program for CFA and SEM. 


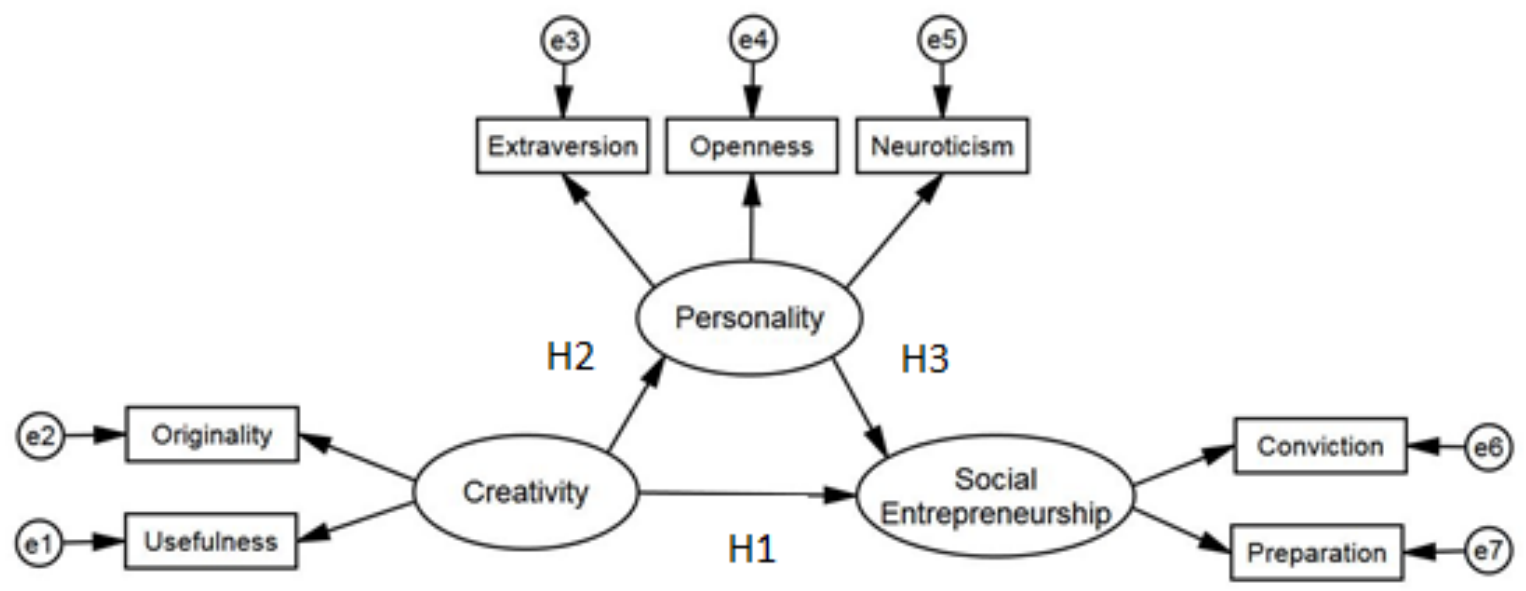

FIGURE 1. Personality mediation model in the relationship between creativity and entrepreneurial intention

\section{RESULTS \& DISCUSSION}

By testing research hypotheses, it is appropriate to adopt a two-step approach in the SEM suggested by Hair et al. (1998). The starting step focuses on the assessment of the measurement model. We used the CFA to assess the goodness of fit and measurement validity. The second step concentrated on the assessment of the structural model. This study identified whether the proposed model best fitted the data or not, and then tested the research hypotheses.

\section{Assessment of the Measurement Model Fit}

To assess the goodness-of-fit of measurement model, this study used the CFA with maximal likelihood estimation to test the reliability and validity of factors. After the CFA processing, we thus modified several dimensions and items of factor structures to enhance measurement model fit. The results are shown in Table 2 . According to the model fit indicators recommended by Hair et al. (1998), we have yielded acceptable results the goodness-of-fit of the measurement model. By measuring the creativity, the two-factor solution, i.e., originality and usefulness, extracted an acceptable model fit $\left(X^{2} / d f=1.727, \mathrm{GFI}=.992, \mathrm{AGFI}=.979, \mathrm{CFI}=.997\right.$, $\mathrm{NFI}=.993, \mathrm{SRMR}=.016$, RMSEA $=.035$ ). Regarding measurement of the personality, the three-factor solution, i.e. extraversion, openness and neuroticism, was drawn an acceptable model fit $\left(X^{2} / d f=2.669, \mathrm{GFI}=.993, \mathrm{AGFI}=.974\right.$, $\mathrm{CFI}=.994, \mathrm{NFI}=.991, \mathrm{SRMR}=.017, \mathrm{RMSEA}=.053$ ). With respect to the social entrepreneurship, the two-factor solution, i.e. conviction and preparation, was got an acceptable model fit $\left(X^{2} / d f=2.081, \mathrm{GFI}=.993, \mathrm{AGFI}=.976, \mathrm{CFI}=.993\right.$, $\mathrm{NFI}=.987, \mathrm{SRMR}=.022, \mathrm{RMSEA}=.043)$.

TABLE 2. Goodness-of-fit indexes for measurement model

\begin{tabular}{lllll}
\hline \hline Goodness of fit Index & Recommended Value & Creativity & Personality & Social Entrepreneurship \\
\hline Chi-square/df & $<3.00$ & $1.727^{*}$ & $2.081^{*}$ & $2.669^{*}$ \\
GFI & $>.900$ & $.992^{*}$ & $.993^{*}$ & $.993^{*}$ \\
AGFI & $>.900$ & $.979^{*}$ & $.976^{*}$ & $.974^{*}$ \\
CFI & $>.900$ & $.997^{*}$ & $.993^{*}$ & $.994^{*}$ \\
NFI & $>.900$ & $.993^{*}$ & $.987^{*}$ & $.991^{*}$ \\
SRMR & $<.080$ & $.016^{*}$ & $.022^{*}$ & $.017^{*}$ \\
RMSEA & $<.080$ & $.035^{*}$ & $.043^{*}$ & $.053^{*}$ \\
\hline \hline
\end{tabular}

Note: * indicates that the estimated results are qualified by the recommended value

\section{Assessment of Construct Validity}

To confirm the factor structures, this study adopted the CFA to confirm validity of constructs used in the measurement model. Following recommended value in previous studies, the assessing criteria of convergent validity include: standardized factor loadings ( $>0.5$ ), squared multiple correlation (SMC > 0.2), composite reliabilities (CR > 0.6), average variance extracted (AVE $>0.5$ ) by each construct (Hair et al., 1998; Joreskog, 1989). This study analyzed the conver- gent validity of questionnaire through the CFA on the items that measure the factors of creativity, personality, and social entrepreneurship. The results of Table 3 indicated that each factor of the measurement model achieved moderate convergent validity. For example, the composite reliability of construct means that a set of indicators of constructs are consistent in the measurement. Similarly, the AVE estimation indicates that a latent construct is able to explain in the observed variables theoretically related. 
TABLE 3. CFA and convergent validity of measurement model

\begin{tabular}{|c|c|c|c|c|c|c|c|}
\hline Constructs & Factors/Observed Variables & SFL & SE & $t$-value & SMC & CR & AVE \\
\hline \multirow[t]{8}{*}{ Creativity } & Originality & & & & & .848 & .777 \\
\hline & I am able to work out a business plan that is unique from others & .799 & .168 & 22.8 & 638 & & \\
\hline & I am good at identifying new market needs & .360 & .204 & 8.7 & .130 & & \\
\hline & $\begin{array}{l}\text { I am able to work out a business plan that can bring about a } \\
\text { market spotlight }\end{array}$ & .919 & .140 & 28.5 & .845 & & \\
\hline & I am able to work out a business plan that can lead the market & .896 & .147 & 27.3 & .802 & & \\
\hline & Usefulness & & & & & .590 & .647 \\
\hline & I am able to adapt flexibly to market changes & .731 & .161 & 15.8 & .398 & & \\
\hline & I am able to consider the preference of target consumers & .784 & .167 & 20.1 & .615 & & \\
\hline \multirow[t]{9}{*}{ Personality } & Extraversion & & & & & .889 & .894 \\
\hline & I tend to be talkative & .873 & .208 & 21.6 & .762 & & \\
\hline & I tend to be outgoing & .915 & .223 & 22.7 & .837 & & \\
\hline & Openness & & & & & .700 & .734 \\
\hline & I tend to be creative & .822 & .342 & 11.4 & .676 & & \\
\hline & I tend to be philosophical & .550 & .285 & 9.6 & .302 & & \\
\hline & Neuroticism & & & & & 668 & .708 \\
\hline & I tend to be I tend to be anxious & .842 & .315 & 13.3 & .709 & & \\
\hline & I tend to be jealous & .750 & .277 & 12.6 & .563 & & \\
\hline \multirow[t]{7}{*}{ Social entrepreneurship } & Conviction & & & & & .786 & .742 \\
\hline & $\begin{array}{l}\text { I would like to start a social enterprise related to environmental } \\
\text { issues }\end{array}$ & .687 & .196 & 14.9 & .370 & & \\
\hline & $\begin{array}{l}\text { I would like to be involved in a social enterprise related to help } \\
\text { disadvantaged groups }\end{array}$ & .777 & .194 & 19.2 & .604 & & \\
\hline & $\begin{array}{l}\text { I would like to be involved in a social enterprise related to pro- } \\
\text { moting environmental sustainability }\end{array}$ & .803 & .170 & 21.8 & .644 & & \\
\hline & Preparation & & & & & .589 & .647 \\
\hline & My professional goal is to become a social entrepreneur & .723 & .198 & 18.9 & .522 & & \\
\hline & $\begin{array}{l}\text { If possible, I will transform family business into a social enter- } \\
\text { prise }\end{array}$ & .788 & .176 & 18.4 & .502 & & \\
\hline
\end{tabular}

Note: $\mathrm{SFL}=$ standardized factor loading; $\mathrm{SE}=$ standard error; $t$-value is at significant level; $\mathrm{SMC}=$ squared multiple correlation; $\mathrm{AVE}=$ average variance extracted; $\mathrm{CR}=$ composite reliability

In addition to convergent validity, we further use the AVE for each construct to assess discriminant validity in the measurement model. Based on suggested criteria of Hair et al. (1998), correlations between constructs in the model must be lower than the square root of AVE. The evidence of discriminant validity between each pair of constructs is shown in Table 4. Take the preparation for starting a social enterprise for example, the square root of AVE was 0.647 while the shared standardized correlation coefficient between preparation and other latent variables ranged from -0.306 to 0.615 . This result confirms the discriminant validity of measurement.

TABLE 4. Correlation matrix and discriminant validity of measurement model

\begin{tabular}{llllllll}
\hline \hline Factors & Originality & Usefulness & Extraversion & Openness & Neuroticism & Conviction & Preparation \\
\hline Originality & .777 & & & & & & \\
Usefulness & $.716^{* *}$ & .647 & & & & & \\
Extraversion & $.474^{* *}$ & $.482^{* *}$ & .894 & & & & \\
Openness & $.365^{* *}$ & $.388^{* *}$ & $.334^{* *}$ & .734 & & & \\
Neuroticism & $-.300^{* *}$ & $-.302^{* *}$ & $-.307^{* *}$ & -.071 & .708 & & .742 \\
Conviction & $.449^{* *}$ & $.436^{* *}$ & $.348^{* *}$ & $.287^{* *}$ & $-.222^{* *}$ & .747 \\
Preparation & $.572^{* *}$ & $.540^{* *}$ & $.447^{* *}$ & $.310^{* *}$ & $-.306^{* *}$ & $.615^{* *}$ & .647 \\
\hline \hline
\end{tabular}

Note: The value on the diagonal (bold form) represents the square root of AVE; the value below the diagonal is the standardized correlation coefficient. ${ }^{*} p<.05,{ }^{* *} p<.01,{ }^{* * *} p<.001$.

\section{Assessment of Structural Model}

The main purpose of this study aims at exploring the effect of personality and creativity on social entrepreneurship explicitly. To assess the model fit of SEM can be evaluated by examining several indices of goodness of fit. As shown in Table 5, the results that the model fit was acceptable $\left(X^{2} / d f\right.$ $=2.276, \mathrm{GFI}=.988, \mathrm{AGFI}=.969, \mathrm{CFI}=.997, \mathrm{NFI}=.984, \mathrm{SRMR}$ $=.027$, RMSEA $=.047$ ), no further modifications were made. 
Therefore, we built a path model consisted of three constructs, including: creativity as the latent independent vari- ables, social entrepreneurship as the latent dependent variable, and personality as the mediation variable.

TABLE 5. Goodness of fit index of SEM

\begin{tabular}{llll}
\hline \hline Goodness of fit Index & Recommended Value & Result of SEM & Result of Assessment \\
\hline Chi-square/ $d f$ & $<3.00$ & $2.276^{*}$ & Accepted \\
GFI & $>.900$ & $.988^{*}$ & Accepted \\
AGFI & $>.900$ & $.969^{*}$ & Accepted \\
CFI & $>.900$ & $.997^{*}$ & Accepted \\
NFI & $>.900$ & $.984^{*}$ & Accepted \\
SRMR & $<.080$ & $.027^{*}$ & Accepted \\
RMSEA & $<.080$ & $.047^{*}$ & Accepted \\
\hline \hline
\end{tabular}

Note: ${ }^{*}$ indicates that the estimated results are qualified by the recommended value

The SEM results revealed that creativity exerted a nonsignificant effect on social entrepreneurship. This result is inconsistent with previous findings that demonstrate the relationship between creativity and entrepreneurship tends to be positively correlated (Chen \& Chen, 2015; Chia \& Liang, 2016; C. Liang et al., 2017). While previous empirical research has suggested that creativity influences entrepreneurial intentions, this finding shows that above relationship mediated by fundamental traits, which is in accordance with empirical study of Karimi et al. (2011). The rejection of Hypothesis 1 is surprising, but not unexpected. The possible explanation maybe results from the fundamental differences between corporate entrepreneur and social entrepreneur. The commercial entrepreneurship is more likely taking risks in order to make profits; whereas the social entrepreneurship seems likely to stress public good or social aims. This finding also implies that the personality will play a mediating role to bridge the gap between creativity and social entrepreneurship.

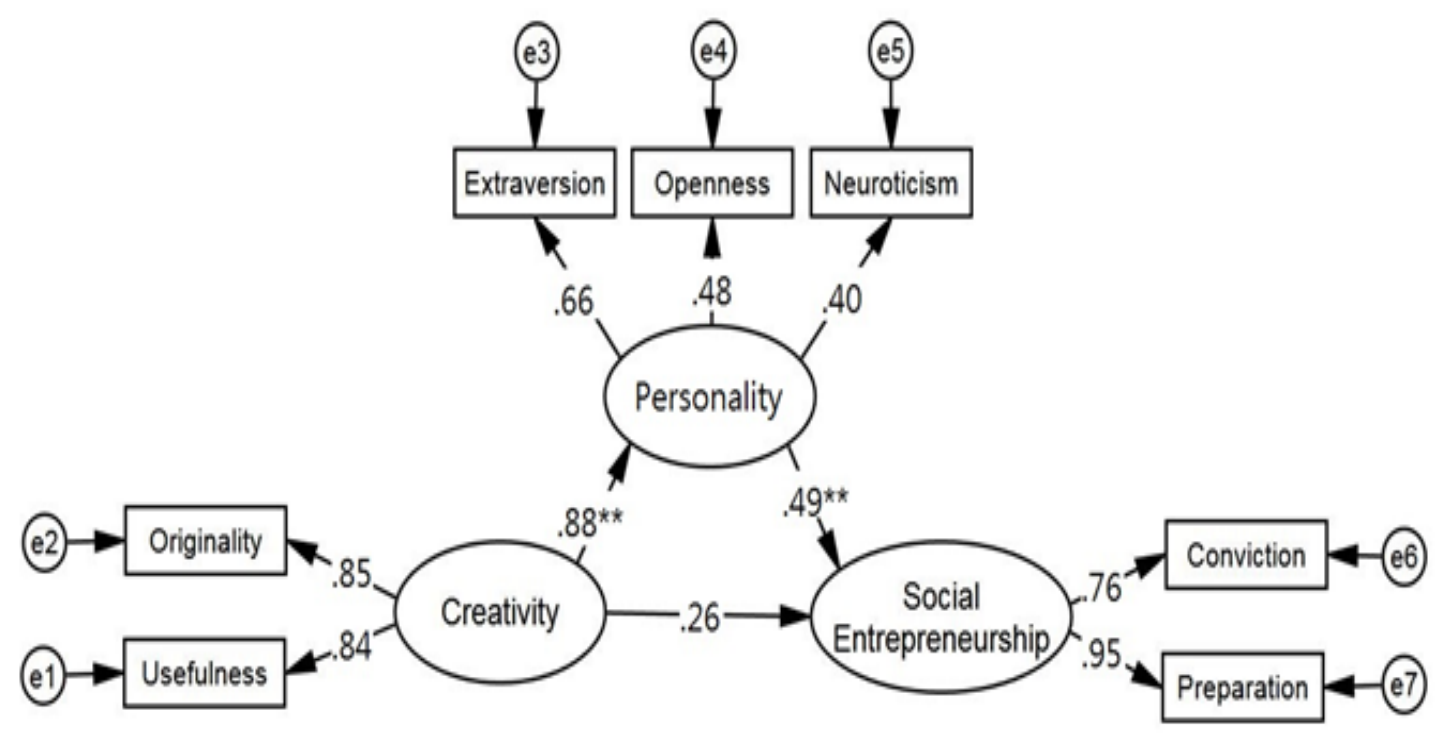

FIGURE 2. Results of SEM of social entrepreneurship

As shown in Figure 2, the other two proposed paths (direct effects) were significant $(p<.001)$ in the structural model. The direct effect of creativity on personality was significant and positive $(\beta=.88 ; p<.001)$, which suggests that $\mathrm{H} 2$ was supported. Further, it was found that the positively direct effect of personality on social entrepreneurship was significant $(\beta=.49 ; p<.001)$, which supported H3. These empirical evidences found in $\mathrm{H} 2$ and $\mathrm{H} 3$ are consistent with earlier findings in the literature (C.-Y. Hsu \& Wang, 2018; C.-T. Liang et al., 2015). A higher level of creative originality and usefulness is positively associated with proactive personality, like extraversion, emotional stability, and openness to experience. In addition, higher levels of positive personality are also related to stronger levels of entrepreneurial conviction and preparation. In summary, the proposed mediation model of social entrepreneurship was 
partially supported. The latent independent variables had a total effect of $.43(=.88 \times .49)$ on the dependent variable (social entrepreneurship). Based on the data analyses, the results showed that students' personality directly facilitates their social entrepreneurship. However, creativity did not affect students' social entrepreneurship, but indirectly through their personality. These findings confirm personality traits can mediate the association between creative factors and entrepreneurial intentions. For those who with higher level of proactive personality are more likely to create new idea, to adopt innovative practices and thus to start up a new business. However, this research failed to provide evidence that creativity has a direct effect on the students' entrepreneurial intentions significantly. The empirical results implied that agricultural educators should pay more attention on students' personality while constructing or implementing programs related to courses of creativity and entrepreneurship.

\section{CONCLUSION}

Encouraging social entrepreneurship for agricultural development is a noticeable trend in the small-scale farming countries. The primary purpose of this research is to introduce the intention literature to investigate the mediating effect of personality traits on the relationship between creativity and attitudes toward social entrepreneurship. According to estimation results of the SEM, this study finds that there is no significant and direct correlation between creativity and social entrepreneurial intention of the agricultural students. Second, there is a significant correlation between personality and creativity. Third, there is a positive and significant correlation between personality traits and social entrepreneurship. Finally, the personality is found as an important mediator of creativity and social entrepreneurship for agricultural students. Our finding is consistent with prior studies (Antonio, Lanawati, Wiriana, \& Christina, 2014; C.-Y. Hsu \& Wang, 2018; C.-T. Liang et al., 2015). This empirical result confirms certain personality characteristics can mediate the relationship between creativity and entrepreneurial intentions of agricultural students. However, this study could not provide evidence that creativity has a significant effect on the students' entrepreneurial intentions. It is different from the studies of Chen and Chen (2015) and Chia and Liang (2016), which use personality traits as significant antecedents of creativity to affect corporate entrepreneurship. The inconsistent findings maybe result from different nature and organizational objective between corporate and social entrepreneurship. In addition, the survey subjects drawn from different col- leges and majors, such as agriculture or multimedia engineering, may be another reason which leads to difference in results. In agreement with the literature, Devine and Clayton (2010) have called for more empirical researches to test new conceptual frameworks that can verify and confirm unclear or contradictory findings. While previous intention models did not consider the mediating role of personality on entrepreneurship, a notable theoretical contribution of this study is that we re-investigate the structural relationship between creativity, personality and entrepreneurial intention. The contribution of this study is to provide empirical evidence for developing and testing structural model of social entrepreneurship in the context of agriculture. Consequently, this study contributes to get better understanding the role of personality trait as an influence key on the relationship between creativity and entrepreneurial intentions.

\subsection{Research Implications}

Several policy implications for the SEM of social entrepreneurship can be inferred. These finding implies that agricultural educators should design and provide tailored entrepreneurial programs that matches students' personality, instead of merely offering creativity training courses. The results also suggest that educators or career advisors may introduce extraversion, openness and emotional control training into creativity courses to facilitate and strengthen students' entrepreneurial intention. For agricultural students who have willingness to engage in social enterprises, the educators should take the positive personality traits into account by designing creative or entrepreneurship programs. Appropriate curriculum design and teaching techniques for students is important for motivation and capability building of social entrepreneurship. Moreover, this study recommended effective approaches for educators to select potential students, design appropriate entrepreneurial courses, as well as to enhance student's intention to devote to social enterprise. Consequently, this study clarified that creativity can facilitate entrepreneurial intention of agricultural students, only through understanding and recognition of individual personality traits and preferences regarding social entrepreneurship.

\section{Limitations \& Future Research Directions}

Although this study sheds light on the mediating role that personality traits can play in bridging creativity and entrepreneurial intention. The limitation of this study remains. First, we used latent variables to conduct a structural model for examining the process of entrepreneurial 
intention. This approach has not controlled for the effect of observed socio-demographic variables on entrepreneurial motivation. Thus, we suggest that further research might adopt multiple regression model to confirm and estimate the mediating effect of personality traits on entrepreneurial intention. Also, applying comparative structural model between different student groups is an alternative approach to confirm the difference in entrepreneurship development, for instance male vs. female, agricultural vs. non- agricultural students. Second, there are relevant explanatory variables, such as self-efficiency, social capital, and domain knowledge, did not discussed in this study. The intention model of social entrepreneurship will be more robust, if further research could take above-mentioned determinants into account. Finally, this study suggests that further entrepreneurial researches could recruit different action groups, like governmental officers, NGOs or social entrepreneur, to investigate their contributions in promoting entrepreneurial activities in rural areas.

\section{REFERENCES}

Adora, N. M. (2017). Entrepreneurial activities and teaching performance of faculty members of the university of Eastern Philippines. International Journal of Business and Administrative Studies, 3(4), 142-151. doi:https://doi.org/ 10.20469/ijbas.3.10002-4

Ajzen, I. (1991). The theory of planned behavior. Organizational Behavior and Human Decision Processes, 50(2), 179-211.

Alvord, S. H., Brown, L. D., \& Letts, C. W. (2004). Social entrepreneurship and societal transformation: An exploratory study. The journal of Applied Behavioral Science, 40(3), 260-282. doi:https://doi.org/10.1177/0021886304266847

Anggadwita, G., \& Dhewanto, W. (2016). Women's entrepreneurial intentions in Micro and Small Enterprises (MSEs) in Indonesia: the influence of environmental factors on perceived behavioral control. Journal of Administrative and Business Studies, 1(1), 1-7. doi:https://doi.org/10.20474/jabs-1.1.1

Antonio, T., Lanawati, S., Wiriana, T. A., \& Christina, L. (2014). Correlations creativity, intelligence, personality, and entrepreneurship achievement. Procedia-Social and Behavioral Sciences, 115(5), 251-257. doi:https://doi.org/10.1016/ j.sbspro.2014.02.433

Ardichvili, A., Cardozo, R., \& Ray, S. (2003). A theory of entrepreneurial opportunity identification and development. Journal of Business venturing, 18(1), 105-123. doi:https://doi.org/10.1037/0021-9010.91.2.259

Berglund, H., \& Wennberg, K. (2006). Creativity among entrepreneurship students: Comparing engineering and business education. International Journal of Continuing Engineering Education and Life Long Learning, 16(5), 366-379. doi: https://doi.org/10.1504/ijceell.2006.010959

Bernik, B., Azis, Y., Kartini, D., \& Harsanto, B. (2015). Managing innovation of smes in creative industry for interactive game subsector and TV and Radio subsector based on local wisdom in development of competitiveness business (Case Study SMEs in Bandung). International Journal of Business and Administrative Studies, 1(2), 49-53. doi:https://doi.org/ 10.20469/ijbas.10001-2

Bizon, W. (2016). Stimulating entrepreneurship by introducing behavioural incentives, propensity to use financial instruments in the context of decision makers' personal characteristics and their financial knowledge in Polish SMEs. Journal of Administrative and Business Studies, 2(6), 270-279. doi:https://doi.org/10.20474/jabs-2.6.2

Chen, S.-C., \& Chen, H.-H. (2015). How does creativity mediate the influence of personality traits on entrepreneurial intention? a study of multimedia engineering students. Journal of Information Communication, 5(2), 73-86.

Chia, C.-C., \& Liang, C. (2016). Influence of creativity and social capital on the entrepreneurial intention of tourism students. Management and Innovation, 12(2), 151-168.

Devine, W. P., \& Clayton, S. (2010). Introduction to the special issue: Place, identity and environmental behaviour. Journal of Environmental Psychology, 30(3), 267-270. doi:https://doi.org/10.1016/s0272-4944(10)00078-2

Fillis, I., \& Rentschler, R. (2010). The role of creativity in entrepreneurship. Journal of Enterprising Culture, 18(01), 49-81. doi:https://doi.org/10.1142/s0218495810000501

Hair, J., Anderson, R., Tatham, R., \& Black, W. (1998). Multivariate data analysis. Upper Saddle River, NJ: Prentice-Hall.

Hsu, C.-Y., \& Wang, S.-M. (2018). Social entrepreneurial intentions and its influential factors: A comparison of students in taiwan and hong kong. Innovations in Education and Teaching International, 1-11. doi:https://doi.org/10.1080/ 14703297.2018.1427611 
Hsu, Y., Peng, L.-P., Wang, J.-H., \& Liang, C. (2014). Revising the imaginative capability and creative capability scales: Testing the relationship between imagination and creativity among agriculture students. International Journal of Learning, Teaching and Educational Research, 6(1), 57-70.

Ip, C. Y., Wu, S. C., Liu, H. C., \& Liang, C. (2018). Social entrepreneurial intentions of students from Hong Kong. The Journal of Entrepreneurship, 27(1), 47-64. doi:https://doi.org/10.1177/0971355717738596

Joreskog, D., K.G. \& Sorbom. (1989). Lisrel-7 user's reference guide. Mooresville, IN: Scientific Software.

Karimi, S., Biemans, H. J., Lans, T., Arasti, Z., Chizari, M., \& Mulder, M. (2011). Application of structural equation modelling to assess the effect of entrepreneurial characteristics on students' entrepreneurial intentions. In Academic Conferences and Publishing International, Kalamata, Greece.

Kerlin, J. A. (2006). Social enterprise in the united states and europe: Understanding and learning from the differences. Voluntas: International Journal of Voluntary and Nonprofit Organizations, 17(3), 246. doi:https://doi.org/10.1007/ s11266-006-9016-2

Kickul, J., \& Lyons, T. S. (2016). Understanding social entrepreneurship: The relentless pursuit of mission in an ever changing world. London, UK: Routledge.

Kolvereid, L., \& Moen, H. (1997). Entrepreneurship among business graduates: Does a major in entrepreneurship make a difference. Journal of European industrial training, 21(4), 154-160. doi:https://doi.org/10.1108/03090599710171404

Krueger Jr, N. F., Reilly, M. D., \& Carsrud, A. L. (2000). Competing models of entrepreneurial intentions. Journal of Business Venturing, 15(5-6), 411-432. doi:https://doi.org/10.1016/s0883-9026(98)00033-0

Lee, S. Y., Florida, R., \& Acs, Z. (2004). Creativity and entrepreneurship: A regional analysis of new firm formation. Regional Studies, 38(8), 879-891. doi:https://doi.org/10.1080/0034340042000280910

Liang, C., Ip, C. Y., Wu, S.-C., Law, K. M. Y., Wang, J.-H., Peng, L.-P., \& Liu, H.-C. (2017). Personality traits, social capital, and entrepreneurial creativity: Comparing green socioentrepreneurial intentions across Taiwan and Hong Kong. Studies in Higher Education, 1-17. doi:https://doi.org/10.1080/03075079.2017.1418310

Liang, C.-T., Chia, T.-L., \& Liang, C. (2015). Effect of personality differences in shaping entrepreneurial intention. Internafional Journal of Business and Social Science, 6(4.1), 166-176.

Luhmann, H., \& Theuvsen, L. (2016). Corporate social responsibility in agribusiness: Literature review and future research directions. Journal of Agricultural and Environmental Ethics, 29(4), 673-696. doi:https://doi.org/10.1007/s10806 -016-9620-0

McCrae, R. R., \& Costa Jr, P. T. (1995). Trait explanations in personality psychology. European Journal of Personality, 9(4), 231-252. doi:https://doi.org/10.1037/0021-9010.91.2.259

Niesing, C. M., Merwe, S. W. D., \& Potgieter, D. M. (2016). The impact of income-generating projects on stimulating the development of entrepreneurial activities in communities: The holding hands case. International Journal of Business and Economic Affairs, 1(1), 36-46. doi:https://doi.org/10.24088/ijbea-2016-11006

Rauch, A., \& Frese, M. (2007). Let's put the person back into entrepreneurship research: A meta-analysis on the relationship between business owners' personality traits, business creation, and success. European Journal of work and organizational psychology, 16(4), 353-385. doi:https://doi.org/10.1080/13594320701595438

Shapero, A., \& Sokol, L. (1982). The social dimensions of entrepreneurship. In C. Kent, D. Sexton, \& K. Vesper (Eds.), The encyclopedia of entrepreneurship. Englewood Cliffs, NJ: Prentice-Hall.

Thompson, E. R. (2008). Development and validation of an international english big-five mini-markers. Personality and Individual Differences, 45(5), 542-548. doi:https://doi.org/10.1016/j.paid.2008.06.013

Thompson, E. R. (2009). Individual entrepreneurial intent: Construct clarification and development of an internationally reliable metric. Entrepreneurship Theory and Practice, 33(3), 669-694. doi:https://doi.org/10.1111/j.1540-6520 .2009.00321.x

Varca, P. E. (2004). Service skills for service workers: Emotional intelligence and beyond. Managing Service Quality: An International Journal, 14(6), 457-467.

Wang, J.-H., Chang, C.-C., Yao, S.-N., \& Liang, C. (2016). The contribution of self-efficacy to the relationship between personality traits and entrepreneurial intention. Higher Education, 72(2), 209-224. doi:https://doi.org/10.1007/ s10734-015-9946-y 
Wang, J.-H., Peng, L.-P., \& Liang, C.-Y. (2014). Developing and testing the psychological variable, rural practice, and entrepreneurial intention scales. Review of Agricultural Extension Science, 5(31), 72-95.

Ward, T. B. (2004). Cognition, creativity, and entrepreneurship. Journal of Business Venturing, 19(2), 173-188. doi:https:// doi.org/10.1016/s0883-9026(03)00005-3

Wennekers, S., \& Thurik, R. (1999). Linking entrepreneurship and economic growth. Small Business Economics, 13(1), $27-56$. doi:https://doi.org/10.1023/a:1008063200484

Zhao, H., \& Seibert, S. E. (2006). The big five personality dimensions and entrepreneurial status: A meta-analytical review. Journal of Applied Psychology, 91(2), 259-321. doi:https://doi.org/10.1037/0021-9010.91.2.259 